\title{
Guild or Union? A Case Study of Rural Dutch Weavers, 1682-1750*
}

\author{
JOYCE M. MASTBOOM
}

\begin{abstract}
Summary: This article discusses the defensive actions taken by a group of weavers in the rural eastern Netherlands in response to changing economic conditions; in particular, how they successfully re-established their weavers' guild to protect them against aggressive local merchants who were out to lower payments for woven cloth. A guild, by organizing many individuals into a group, could wield much more power than separate weavers on their own. But that was not all. Local weavers were aware that economic circumstances had changed, and that a new charter would have to be adapted so that it addressed the problems they faced. Hence, the charter they drafted provided for a guild that had the outward appearance of the old form of craft organization. However, in addition to the usual regulations it contains clauses that are more reminiscent of a trade union than a guild. The result was an organization that the weavers could use effectively to fend off their growing dependence on and subordination to merchants.
\end{abstract}

Recent discussions of the position of workers in the early modern period have moved away from the view that the arrival of merchants on the production scene quickly led to the disappearance of independent craft workers, and to the rise of early capitalist forms of production with a labor force that had little power. On the one hand, it has been shown that in some instances merchants were not necessary for the development of early capitalism: export-oriented industries could develop under an organization of small commodity production that combined traditional features with new elements to form a system suitable to market-oriented industries and to traditional urban societies. ${ }^{1}$ On the other hand, it is becoming clear that where that kind of adaptation did not occur, and where merchants inserted themselves between the producers and the market, workers found innovative ways to defend their traditional position. ${ }^{2}$

A second debate that has developed recently concerns the function and role of guilds in early modern society and the connection between guilds

*I would like to thank Karel Davids, David Goldberg, Roger Manning, Peter Meiksins, and Wayne te Brake for their helpful comments and criticisms on earlier versions of this article.

'Robert DuPlessis and Martha C. Howell, "Leiden, Lille and the Early Modern Economy", Past \& Present, XCIV (1982), pp. 49-84.

2 See Rudolf Dekker, "Labour Conflicts and Working-Class Culture in Early Modern Holland", International Review of Social History, XXXV (1990), pp. 377-420.

International Review of Social History 39 (1994), pp. 57-75 
and the trade union movement of the nineteenth century. ${ }^{3}$ Some historians argue that guilds continued to function in the seventeenth and eighteenth centuries because, despite charters and regulations, they were flexible in reality and people found them useful to achieve their own individual goals. Others argue that guilds survived that long because they fulfilled important institutional functions such as collecting taxes for the authorities. Yet others have written that guilds survived at least in part because of the collective power they gave to individuals who would have been weak without the organization. ${ }^{4}$

This article analyses the unusual organization adopted by weavers in the village of Winterswijk (located in an eastern part of Gelderland, known as the Achterhoek - see Maps 1 and 2) during the last quarter of the seventeenth century. The organization was set up at a time when the weavers faced an offensive by local merchants who attempted to reduce payments for weaving. If weavers did not comply, the merchants threatened to take their orders elsewhere. This threat was not an idle one, and from around 1650 a Europe-wide agrarian depression began to affect the eastern Achterhoek. In response, peasants in the countryside surrounding the village were more than willing to earn a supplementary income by weaving in their spare time. Even worse, only a few miles away across the border, German peasants who had a lower standard of living gladly accepted smaller payments per piece of cloth.

Under these circumstances, and in the face of the aggressive tactics adopted by the merchants, the weavers of Winterswijk appealed to their overlord and asked for the re-establishment of their linen guild. They did not want a traditional guild, however, which would merely restrict access to the trade and supervise craftsmanship and quality. They wanted protection under the new conditions, and therefore drafted a new charter for approval by their overlord who duly signed it on 18 April $1682 .{ }^{5}$ It authorized a guild that had the outward appearance of the old form of craft

'See, for instance, Charles R. Hickson and Earl A. Thompson, "A New Theory of Guilds and European Economic Development", Explorations in Economic History, XXVIII (1991); Bo Gustafsson, "The Rise and Economic Behaviour of Medieval Craft Guilds", in idem (ed.), Power and Economic Institutions. Reinterpretations in Economic History (Brookfield, VT, 1991); Jan Lucassen, "Het Welvaren van Leiden (1659-1662): de wording van een economische theorie over gilden en ondernemerschap", in Boudien de Vries et al. (eds), De Kracit der Zwakken. Studies over Arbeid en Arbeidersbeweging in het Verleden (Amsterdam, 1992). Maarten Prak, "'Een Verzekerd Bestaan.' Ambachtslieden, Winkeliers en hun Gilden in Den Bosch (ca. 1775)", in De Vries et al., De Kracht der Zwakken. Recent contributions to the debate on continuity are: Rudolf Boch, "Zunfttradition und fruhe Gewerkschaftsbewegung", in Ulrich Wengenroth (ed.), Prekare Selbständigkeit. Zur Standortbestimmung von Handwerk, Hausindustrie und Kleingewerbe im Industrialisierungsprozeß (Stuttgart, 1989); Dekker, "Labour Conflicts"; Jan Lucassen, Jan, Jan Salie en diens kinderen. Vergelijkend onderzoek naar continulteit en discontinutteit in de ontwikkeling van arbeidsverhoudingen (Amsterdam, 1991).

4 See Prak's summary of the debate in "'Een Verzekerd Bestaan"', pp. 51-54, 75-79.

3 Gemeente Archief (G.A.) Winterswijk, Archief Weversgilde, "Gilde-brief voor die van't Weversambagt tot Winterswijck". 


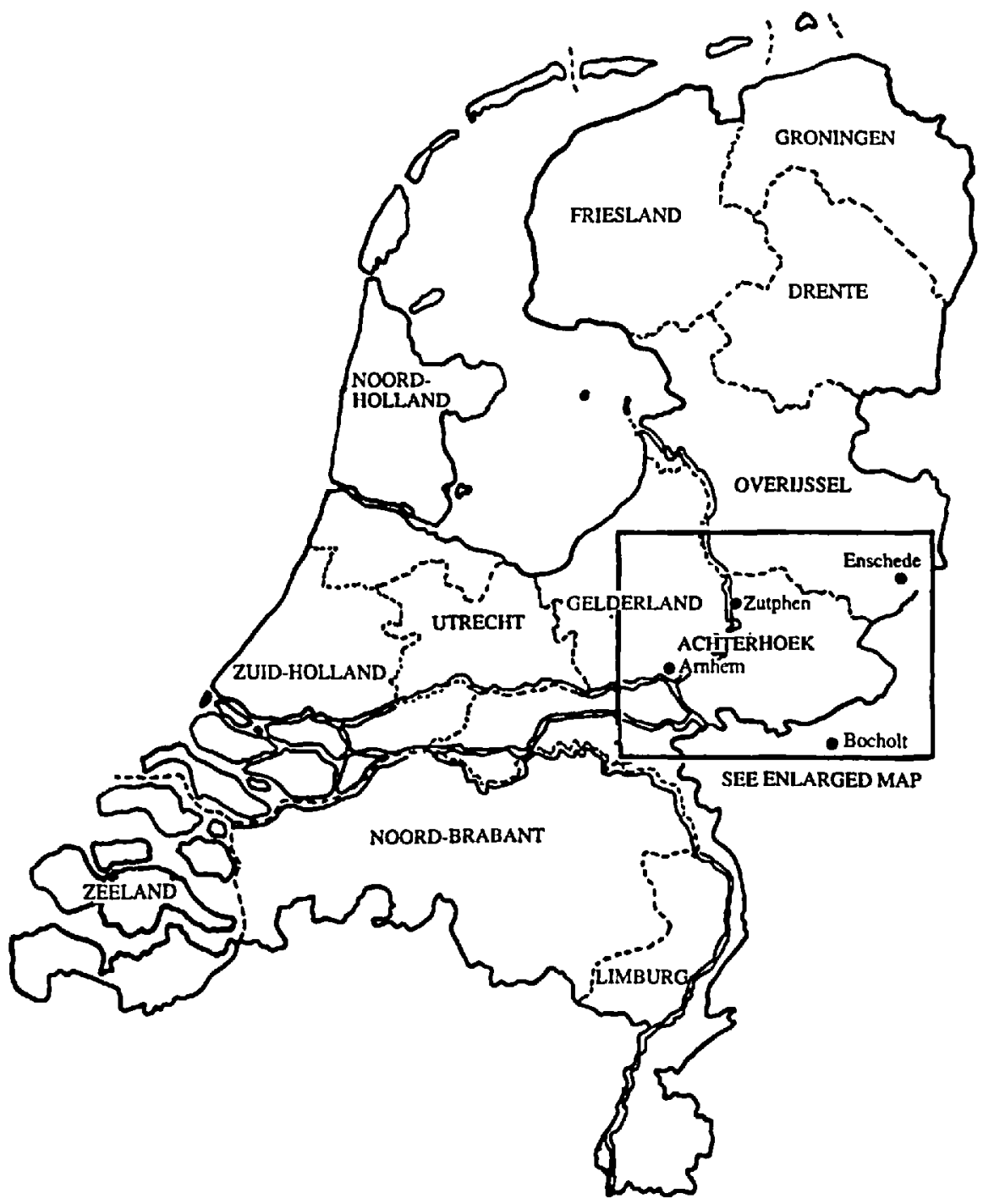

Map 1. The Netherlands

organization, but in addition to the usual regulations, the charter contains clauses that are more reminiscent of a trade union than a guild. Hence, the Winterswijk weavers' guild appears to be a hybrid organization; one that used a form and structure that dated back to the Middle Ages, but that fulfilled a function suggestive of present day unions. ${ }^{6}$ The result was an organization that the weavers could use to fend off their increasing dependence on and subordination to merchants.

- By "present day unions" I mean organizations of wage-laborers formed for the express purpose of negotiating a labor contract with their employer through collective bargaining. 


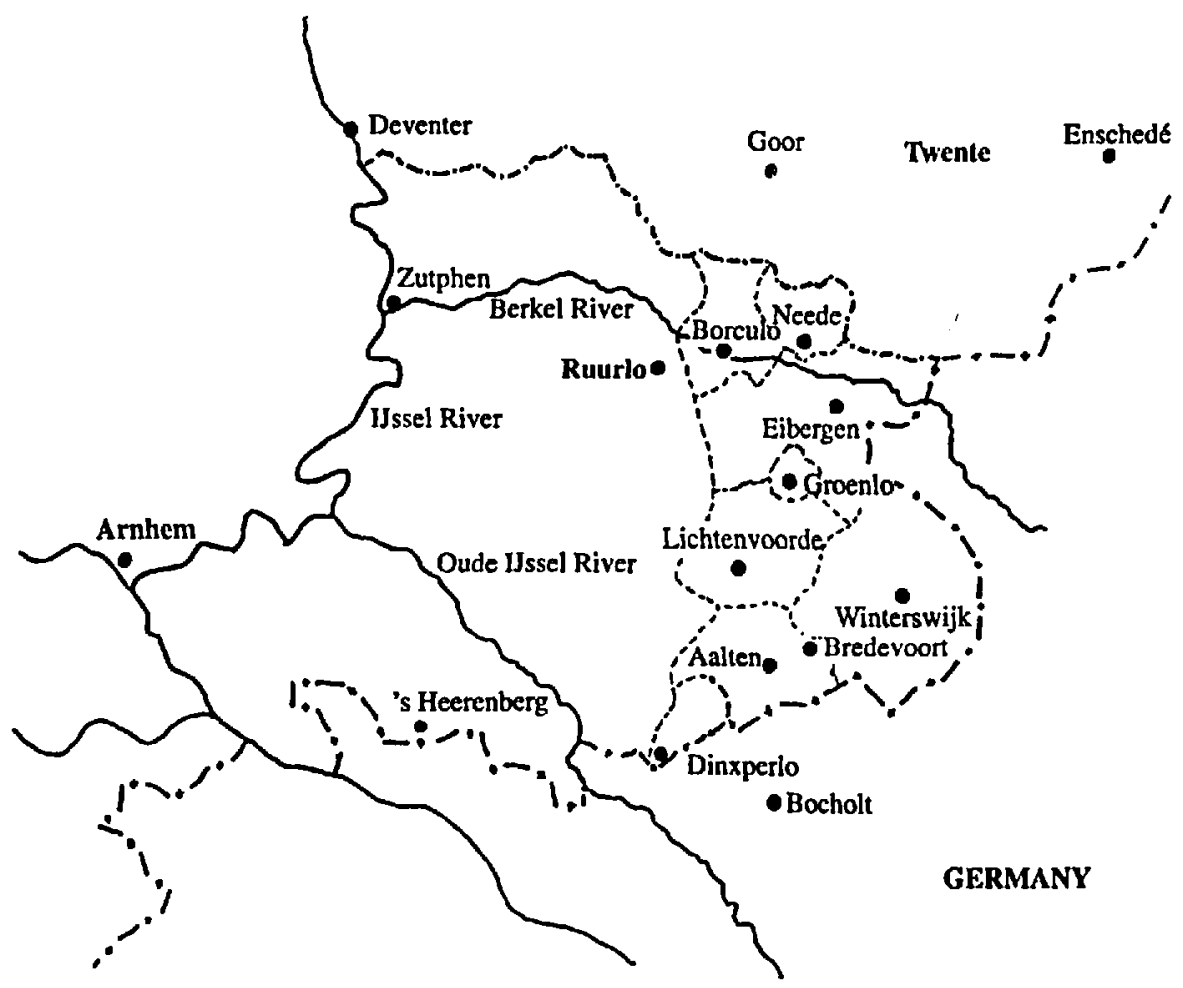

Map 2. Achterhoek

The analysis of the Winterswijk guild shows not just that weavers were innovative in defending themselves, it also contributes to the debate about the function of guilds in the early modern period. With regard to the connection between guilds and trade unions, no evidence has been found to suggest an organizational continuity between the Winterswijk guilds and later unions in the area. However, it is argued here that the function of the Winterswijk guild reminds one of unions because local weavers used guild organization as a means to protect their collective interest against merchants. Through personal experience they knew that without organization and collective action individual weavers could not stand up against merchants. Indeed, as Maarten Prak has pointed out, one of the reasons for the continued existence of guilds in the seventeenth and eighteenth centuries is the fact that they could wield power where individuals could not; power derived from being an association, a union of people. Because guilds had an organization and controlled funds they turned individual interests into collective ones, as well as putting guilds in a position to protect those collective interests. ${ }^{7}$ But the Winterswijk weavers went further. Not only did they want to act as a group and therefore wanted their

T Prak, "'Een Verzekerd Bestaan'", p. 77. 
guild reinstated, but they incorporated changes in an otherwise traditional guild charter that shifted the function of the guild from regulator of craft production toward negotiator and enforcer of the charter against merchants. It is that aspect that is suggestive of present day unions.

This article begins by outlining the history of weaving and agriculture in the eastern Achterhoek, followed by an analysis of two guild charters. One is the Winterswijk guild charter, authorized in 1682, and the other is a charter awarded to the town of Borculo, a mere fifteen miles from Winterswijk, which was signed in $1655 .^{8}$ This charter is distinct from Winterswijk's because it set up a strictly traditional organization. A comparison of the two will help to underscore the nature of the Winterswijk weavers' guild.

\section{LINEN WEAVING}

Spinning and weaving were old skills found in the eastern Achterhoek; for many years the agricultural population had grown flax and woven linen cloth for their own use. Most farms had a loom used primarily during the winter when there were fewer agricultural tasks. Aside from filling demand within the household, linen cloth often formed part of servants' wages, and if there was any surplus, it was taken to one of the regional markets to generate cash.

The scant information available for the period before 1650 indicates that even by the sixteenth century merchants (reders) had become involved in this rural handicraft. Initially, they only bought cloth the farmers did not need for themselves; but over time they began to place orders. They arranged to have the cloth bleached and took it to the regional markets in Zutphen and Doetinchem, where they bought and sold other goods as well.. Although spinning and weaving had been a part-time occupation, the involvement of merchants and demand for linen soon led to the appearance of full-time weavers who formed guilds in many of the rural villages. ${ }^{10}$

This successful period of manufacturing and trade in the Achterhoek did not last. The Eighty Years' War between Spain and the Netherlands (1568-1648) and the Thirty Years' War in Germany (1618-1648) affected the area severely. As border territory it saw many battles, and the population constantly suffered from roaming and plundering soldiers. Time and

- G.A. Borculo, Oud Archief, "Kopie van de op 29 Juli 1655 door graaf Otto van Limburg Styrum uitgegeven Gildebrief voor het linnenweversgilde te Borculo".

'H. Tolsma, “"Reders' en 'wevers' in Winterswijk", Nieuwe Winterswijkse Courant, 15 April 1966; J. A. P. G. Boot and A. Blonk, Van Smiet-tot Snelspoel (Hengelo, 1957), pp. 12-13; J. G. van Bel, De Linnenhandel van Amsterdam in de XVIIle Eeuw (Amsterdam, 1940), pp. 14-15, 20.

${ }_{10}$ P. E. van Bemmel, "De Ontwikkeling van de Industrie in den Achterhoek", Koninklijk Nederlands Aardrijkskundig Genootschap, 2nd series, XLIV (1927), pp. 337-338. 
again, Dutch and enemy armies marched through the Achterhoek. ${ }^{11}$ Obviously, under such circumstances trade and manufacturing suffered. Indeed, the preamble to the Winterswijk charter of 1682 makes clear that a chartered guild had existed long before, but that it had lapsed as a result of the "long years of war". ${ }^{2}$

Around the middle of the seventeenth century the situation changed. The wars ended and trade was resumed. From 1655 manufacturing expanded, supported by a new import duty of 6 per cent on all imported linens, and facilitated by the long tradition of textile weaving in the eastern Achterhoek. ${ }^{13}$ Weavers in towns such as Borculo believed that good times had returned, so that in 1655 they requested their overlord to establish, or more likely to reactivate their guild.

The growth of the linen trade was accompanied by changes in the organization of production. Demand became so great that the local supply of flax was inadequate, forcing merchants to procure yarn from the regions of Holland and Zeeland, as well as across the border in Münsterland, Brunswick and eventually from as far away as Silesia. ${ }^{14}$ This yarn was then supplied to weavers to be made into cloth. As a result, the role of merchants increased in importance because they not only took care of bleaching and marketing finished cloth but also controlled the raw materials, while weavers no longer owned the cloth that they wove, but were paid per piece. Hence, they became dependent on merchants.

Another change in the organization of production was the attempt by merchants to employ more weavers in areas not controlled by guilds. The removal of manufacturing from cities to the countryside occurred all over Europe during the second half of the seventeenth century. Merchants wanted flexibility to expand or change production suited to market needs, and guilds imposed too many regulations and restrictions on them. ${ }^{15}$

Although the eastern Achterhoek was primarily rural and, with its neighboring territories, was a beneficiary of this shift on a national level,

"P. A. M. Geurts and A. E. M. Janssen, "1566-1609" , in Geschiedenis van Gelderland 1492-1795 (Zutphen, 1975), pp. 97-131; J. J. Poelhekke, "1609-1672", in Geschiedenis van Gelderland, pp. 133-210. Note the manuscript on p. 160 which lists the various armies that marched through and stayed in the Achterhoek between 1622 and 1629.

12 G. A. Winterswijk, Archief Weversgilde, "Gilde-brief".

${ }^{13} \mathrm{H}$. Tolsma, "Het onstaan van de textielindustrie te Winterswijk", in Mozalk van Winterswic (Winterswijk, 1980), p. 83.

${ }^{14} \mathrm{~J}$. A. P. G. Boot, "Fabrikeurs en textielzaken omstreeks 1750", Textielhistorische Bijdragen, V (1964), p. 18, "Het linnenbedrijf in Twente omstreeks 1700", Textiel. historische Bijdragen, VII (1966), pp. 22-23, 28, and "De markt voot Twents-Achterhoekse weefsels in de tweede helft van de 18de eeuw", Textielhistorische Bijdragen, XVI (1975), pp. 21-22.

is See Jan de Vries, The Economy of Europe in an Age of Crisis, 1600-1750 (Cambridge, 1976), ch. 3. Myron P. Gutmann, Toward the Modern Economy: Early Industry in Europe 1500-1800 (New York, 1988), pp. 90-96. In some areas of Europe this movement was alseady well under way in the sixteenth century. 
a similar development took place within the region. ${ }^{16}$ Merchants began to employ more peasants on farms surrounding the villages, thereby avoiding guild restrictions. As mentioned above, the area had a long tradition of textile weaving and many peasants had the necessary skills and equipment. However, this begs the question of why peasants were willing to devote more labor to weaving at this time.

\section{AGRICULTURE}

In the eastern Achterhoek agriculture consisted of a mixture of arable and cattle farming where animals were kept for the benefit of the arable. Large wastes had to be maintained for grazing, which peasants also used to cut turf to augment manure needed for improving the infertile sandy soils. ${ }^{17}$

This condition and the natural state of the area (i.e. its division into strips by numerous small rivers and streams) worked against the exploitation of land in large units. Although some large farms could be found, small- to medium-sized holdings dominated: the majority consisted of between 1 and 6 hectares ${ }^{18}$ Since one needed approximately $2.5-3$ ha to survive, peasants on smaller holdings could not subsist on their land and had to take up by-employment: they provided labor on larger farms or took up by-occupations. ${ }^{19}$

The mixture of arable production and animal husbandry meant that farms were labor intensive and to some extent self-sufficient. The family household provided most labor, but additional help came from live-in servants and extended family members. A high percentage of rural households in the eastern sandy regions included servants: often young people paid primarily in food and lodging who became virtually part of the family. ${ }^{20}$ This sector made up as much as $10-15$ per cent of the total population, and although farms relied primarily on family labor, the presence of servants allowed farmers to be flexible in the face of changing agricultural circumstances. ${ }^{21}$ Moreover, three-generation households, in which one or

${ }^{26}$ The Haarlem linen industry is a good example of this shift on the national level. See De Vries, The Economy of Europe, p. 97.

17 J. C. Pape, "Oude Bouwlandgronden in Nederland", Boor en Spade, XVIII (1972), p. 113; B. H. Slicher van Bath, "Geschiedenis van de Nederzettingen in de Graafschap Zutfen", Bijdragen en Mededelingen van de Vereeniging 'Gelre', XLVIII (1946).

${ }^{18}$ Joyce M. Mastboom, "The Role of Eastern Gelderland in Dutch Economic Development, 1650-1850" (Ph.D., Brandeis University, 1990), pp. 70-75.

19 B. H. Slicher van Bath, Een Samenleving Onder Spanning. Geschiedenis van het Platteland in Overijssel (Assen, 1957; rep. Utrecht, 1977), p. 584; H. K. Roessingh, "Beroep en Bedrijf op de Veluwe in het Midden van de Achttiende Eeuw", A.A. G. Bijdragen, XIII (1965), p. 204.

20 Thirty-two per cent of households in the Veluwe and Twente, and 39 per cent in the arable region of Salland had live-in servants. See A. M. van der Woude, "Demografische Ontwikkeling van de Noordelijke Nederlanden 1500-1800", in Algemene Geschiedenis der Nederlanden, $\mathrm{V}$ (Haarlem, 1980), p. 158.

${ }^{21}$ H. K. Roessingh, "Landbouw in de Noordelijke Nederlanden 1650-1815", in Algemene Geschiedenis der Nederlanden, VIII (Haarlem, 1979), p. 50. Van der Woude, "Demografische Ontwikkeling", p. 158. 
more grandparents lived with children and grandchildren, were not unusual. ${ }^{22}$ Additional labor sometimes came from live-in unmarried brothers and sisters, a situation not uncommon because of the local inheritance system adhered to by some. With the so-called Anerbenrecht, it was assumed that the eldest son or a designated younger child would inherit the undivided farm. When he or she married, the couple and their children would continue to live and work the holding under the authority of the parents until they died. Theoretically, siblings were entitled to some share in the inheritance, but in practice it was hard to convert a piece of the farm into cash. However, if they remained unmarried, they could continue to live and work on the farm, and this happened especially to younger sons which meant that many farms had additional labor available. ${ }^{23}$ Admittedly, farms sometimes had an overabundance of labor, particularly during the winter months when there was less work. In this way, extended families and Anerbenrecht contributed to underemployment.

Finally, should they require more labor, farmers could call upon smallholders who needed by-employment to survive. Certainly, the area did not have enough large farms to provide employment to many, but the heavy and intensive work associated with turf-manuring and harvesting created labor demands at certain times of the year.

Considering this situation in agriculture, it appears that the eastern Achterhoek had all the conditions necessary for the expansion of rural manufacturing: on the one hand, many holdings that would be in trouble if the economic climate changed for the worse; on the other hand, peasant households whose members were underemployed. Potentially, this made the region suitable for merchants to recruit workers, and for peasants to take up manufacturing. The only ingredient needed was a downturn in the agrarian economy at a time when merchants were looking for workers.

\section{ECONOMIC DEPRESSION}

The new "era of linen" began circa 1650 . It coincided with the start of a period of expanding population and declining agricultural prices that caused a depression in agriculture.

Although specific data are lacking for the eastern Achterhoek itself, similar regions immediately to the north and east experienced rapid population growth between 1650 and 1750 . To the north, the population of Twente (whose economic development paralleled that of the eastern

22 Van der Woude, "Demografische Ontwikkeling", p. 161.

23 D. van Blom, "Boerenerfrecht (met name in Gelderland en Utrecht)", De Economist, LXIV (1915), pp. 849ff. E. W. Hofstee, De demografische ontwikkeling van Nederland in de eerste helft van de negentiende eeuw (n.p., 1978), p. 105. D. de Boer, "Achterhoek en Lijmers", in G. J. A. Mulder (ed.), Handboek der Geografie van Nederland, V (Zwolle, 1955), p. 463. Van der Woude, "Demografische Ontwikkeling", p. 165. 
Achterhoek) trebled, and a similar development took place in the neighboring German districts of Osnabrück and Münster. ${ }^{24}$ Together these four areas formed one economic region and the population of the eastern Achterhoek probably fit the characteristics of that larger region. ${ }^{25}$ Even if its population grew less dramatically than in Twente, pressure on the land increased between 1650 and 1750 in an area where the soil was not fertile and where agricultural techniques limited the amount of land that could be cultivated.

In addition to problems caused by population growth, Achterhoekers faced worsening economic conditions as a result of a Europe-wide agrarian depression. Prices on regional markets closely followed those in the western part of the country - especially Amsterdam - which in turn were determined by international prices. Hence, the international economic situation directly affected the Achterhoek. ${ }^{26}$ Around the middle of the seventeenth century, grain prices in Europe declined significantly. Animal products and commercial crops such as flax declined somewhat less; wages remained constant or declined more slowly. ${ }^{27}$ As a result, eastern Achterhoek farmers derived less income from grain, while at the same time the relative cost of running a farm went up as rents and wages lagged behind. By cutting back on labor, farmers tried to control their expenses, adversely affecting laborers and smallholders dependent on outside work.

Even though they had limited options, however, the rural population did not remain passive. By intensifying production and expanding the cultivation of grain and buckwheat, they tried to relieve some of the economic pressure. But limits were reached quickly, and a more effective solution was found by going outside agriculture: in the eastern Achterhoek peasants turned to textile manufacturing to survive the depression. ${ }^{28}$

\section{RURAL WEAVERS VS. MERCHANTS}

During the agrarian depression many people were both willing and able to produce cloth for the market; in order to survive peasants shifted their attention from farming towards weaving. How far the shift went depended on individual circumstances, but some switched all the way to weaving full-time. This change in emphasis benefited not only the agricultural

24 J. A. Faber et al., "Population Changes and Economic Developments in the Netherlands: A Historical Survey", A.A.G. Bijdragen, XII (1965), pp.74-76, 94. Van der Woude, "Demografische Ontwikkeling", pp. 130-132.

${ }_{25}$ H. J. Keuning, Het Nederlandse Volk in zijn Woongebied (The Hague, 1965), pp. 281282, 279.

${ }^{26}$ Roessingh, "Landbouw", p. 53.

77 B. H. Slicher van Bath, De Agrarische Geschiedenis van West-Europa 500-1850 (Utrecht, 1960), pp. 230-231. W. Abel, Agrarian Fluctuations in Europe: From the Thirteenth to the Twentieth Centuries, trans. Olive Ordish (New York, 1980), pp. 158-161.

${ }^{23}$ Roessingh, "Landbouw", pp. 54-55. 
population, but also merchants who gained by having plenty of labor available at a time when they could sell large quantities of linen, and were looking for a labor force not restricted by guilds. ${ }^{29}$

Hence, by the last quarter of the seventeenth century the following situation existed in the eastern Achterhoek. To supply a large international demand, merchants employed weavers to produce linen from yarn supplied by them. Many of these weavers were peasants who lived outside the jurisdiction of village guilds and had to weave to supplement their income. Consequently, they were in a weak position to bargain over piece rates, which, in any case, were low..$^{30}$

Competition from the countryside must have caused major problems for full-time weavers in towns and villages who saw their pay rates go down or their livelihood disappear. Because merchants supplied yarn, weavers were already dependent on them, and competitive low-cost labor weakened their bargaining position further. Few records showing their response to this situation in the eastern Netherlands have survived. An exception, however, is the 1682 charter of the Winterswijk weavers' guild, which reveals that weavers there fought back vigorously.

In some ways, the position of Winterswijk weavers was worse than elsewhere. Not only did they face competition from peasant weavers outside the village but also from across the border in Münsterland where the standard of living was lower. ${ }^{31}$ Merchants used that situation to force weavers to accept payments in kind or lower wages and, in response to that onslaught, the weavers tried to get protection by petitioning their overlord to reinstate their guild. Supporting arguments for the request appear in the preamble to the charter:

[since] the above mentioned weavers' guild and its privileges have been neglected as a result of the long years of war, and [since] the petitioners, situated on the border of another country, had to tolerate and endure that they were passed over and deprived of all the advantages that they had before, and [...] [since] the linen merchants will not have cloth woven except for payment of goods and manufactures, and when [the weavers] could not do that were passed over and the yarn carried out of the country to foreign places to the notable loss and ruin of the

${ }^{29}$ Much linen was exported to England and Spain, though that changed in the second half of the eighteenth century. For more information see N. B. Harte, "The Rise of Protection and the English Linen Trade, 1690-1790", in Textile History and Economic History. Essays in Honour of Miss Julia de Lacy Mann (Manchester, 1973), and Bel, De Linnenhandel van Amsterdam.

${ }^{30}$ According to Jan de Vries: "To the extent that industrial by-employment utilized the dead time between the seasonal peaks of agricultural labor demand, its opportunity cost (the value of the time in available alternative employment) was very low indeed." See The Economy of Europe, p. 85.

${ }^{31}$ Wages and costs were lower by as much as 20 per cent. Rijksarchief in Gelderland, archief van Staten van Kwartier van Zutphen en hun Gedeputeerden, nr. 233b, "Requesten ingekomen bij Gedeputeerde Staten" 1592-1805, bI 1592-1756, "Request uit 1732 van coopluyden in Winterswijk". 
petitioners, and [ . . . [ [since] as a result they are deprived of the wages and income which they must have for their subsistence and to fulfill their duties to the overlord [...] [I award this charter]. ${ }^{32}$

Tactfully, in their desire to receive protection from merchants, they did not forget to appeal to their overlord's self-interest as well.

The passage quoted clearly shows that the primary purpose of reinstating the guild was to protect weavers from merchants, rather than craft regulation. Linen merchants are mentioned explicitly in both the preamble and the text (Article 3) which proves how important and powerful they had become: weavers could no longer think about their craft in isolation from them.

In comparison, the nearby town of Borculo received a guild charter in 1655 , less than thirty years before Winterswijk. It does not mention merchants, and there is no suggestion of a dependent relationship between them and weavers. ${ }^{33}$ Of course, in 1655 the agrarian depression and linen boom had barely begun, and the balance of power had not yet shifted decisively in favor of merchants. Therefore, there was no reason for the Borculo weavers to go beyond a traditional guild organization: one whose purpose was restricting access to the trade, regulating it, and limiting the size of individual operations. Indeed, they received the charter soon after peace had returned to the area, and setting up a guild was probably part of a settling down process when things returned to normal, rather than a reaction to new conditions.

By 1682, however, when the people of Winterswijk asked for a guild, the economic situation had changed considerably. A traditional organization would not necessarily offer the kind of protection needed when merchants were bypassing guilds by going to the countryside. But the weavers recognized the problem they were up against. They themselves drafted the charter that their overlord signed, which ensured that it was appropriate for the purpose..$^{34}$

First, the charter applied to all weavers in the village and the parish of Winterswijk that included ten hamlets in the surrounding countryside. ${ }^{35}$ In other words, the guild claimed jurisdiction not only over village weavers as they had done in the past, but also over all peasants around it who wanted to weave. They, too, had to join and follow its regulations. In this way the village weavers defended themselves against "unfair" competition (i.e. undercutting pay rates) from them. ${ }^{36}$

32 G.A. Winterswijk, Archief Weversgilde, "Gildebrief". All translations from Dutch are my own.

${ }^{33}$ G.A. Borculo, Oud Archief, "Kopie van de op 29 Juli 1655 [. . . ]".

34 "[. . . ] for which brotherhood or Guild, afore-mentioned petitioners had prepared some articles for our approval [. . .]", G.A. Winterswijk, Archief Weversgilde, "Gildebrief".

is "[...] those of the weaving trade in the Village and parish Wenterswick [. . .]", ibid.

${ }^{36}$ See also G.A. Winterswijk, Archief Weversgilde, nr. 31, "Stukken betreffende het verzet van de wevers buiten het dorp Winterswijk [. . .]", 1684-1686, "Brief van de heer Griff. Tollius", 27 July 1684. 
Second, they protected themselves against the enterprising merchants through Article 3 which stated that no work could be done outside the guild. ${ }^{37}$ This safeguarded the weavers from German competition because German weavers could not join. Punishment for employing outsiders was a fine and confiscation of the yarn, which was to be handed over to the guild.

These are unusual provisions for a guild charter, but appropriate for late seventeenth-century conditions. Indeed, in a sense, the Winterswijk weavers were fortunate that their previous charter had lapsed, and that it took them a while to ask for reinstatement. By 1682 they knew what the merchants were up to, and were in a position to draft a charter accordingly.

The Borculo weavers, of course, had not been in such a position. Their 1655 charter included a standard guild provision, that outsiders who came to Borculo could not join without becoming a citizen. ${ }^{38}$ It did not even occur to them that outsiders could weave outside and give them stiff competition. That points out the fundamental contrast between the Borculo and Winterswijk guilds: the first restricted access to the trade in a traditional fashion, while the second intended to compel anyone in the area who wove to be a member. While the first organization harked back to the Middle Ages, the second attempted to deal with new relations of production, and tried to be the seventeenth-century equivalent of a "union shop".

Apparently, not just Winterswijk weavers thought that their remarkable charter would be effective in counteracting merchants' actions. It worried local merchants and some "outside" weavers who immediately tried to revoke it. They wrote letters to the overlord as well as the ruling body of the region, arguing that the charter unfairly favored weavers from the village ${ }^{39}$ A local official who investigated the complaints, however, found them baseless. His report of 1684 claims that village and outside weavers were treated equally and that the only reason the guild had been reinstated was "to maintain rule and order between people of a trade and all monopolies and to prevent clandestine circumventions". ${ }^{40}$ Angrily he wrote that

37 "That no work is to be done outside the guild, [subject to punishment of] confiscation of the yam by the guild, and [payment of] six gold guilders to the officer [...]", G.A. Winterswijk, Archief Weversgilde, "Gildebrief".

33 "[...] those who come from outside and are not citizens, first have to earn citizen status and may then earn guild membership [. . .]", G.A. Borculo, Oud Archief, "Kopie van de op 29 Juli 1655 [ . . . ]".

${ }^{39}$ See G.A. Winterswijk, Archief Weversgilde, nr. 30, "Verzoek aan de Drost van Bredevoort door de Staten van Zutphen [...]", 28 April 1686; nr. 31, "Stukken betreffende het verzet van de wevers buiten het dorp Winterswijk [. . .]", 1684-1686; and Algemeen Rijksarchief, The Hague (A.R.A.), Nassause Domeinraad - Hingman nr. 5499, 4. "Papieren raakende het Weversambagt onder Winterswijk [ . . .".

" G.A. Winterswijk, Archief Weversgilde, nr. 31, "Stukken betreffende het verzet [ . . .]", 1684-1686, "Brief van de heer Griff. Tollius", 27 July 1684. 
foreigners or those merchants and weavers living on the border had misrepresented the situation, making it appear to the regional government as if "the introduction of rules to prevent disorders and collusions depopulated the country". ${ }^{41}$ The matter dragged on for a few years but the charter was not revoked.

How did the guild win this first battle so easily? It is likely that their victory was somewhat fortuitous because their overlord happened to be William of Orange, who was also stadholder of Gelderland. He had been elevated to the stadholdership suddenly in 1672 as a result of a general panic caused when Louis XIV and his allies successfully invaded the Republic. In 1675 , after the withdrawal of the enemy, William had managed to increase his political power considerably by imposing a new governmental regulation (regeringsreglement) on Gelderland that gave him control over most provincial and municipal offices, as well as regional and district ones. Most affected had been the economically increasingly important burghers in the cities who traditionally had shared in political power, and many of whom had supported a proposal in 1650 not to appoint William as stadholder following his father's death. After 1675, William could limit the power of these enemies by not appointing them, and instead awarded his supporters with positions, especially the nobility. ${ }^{42}$ The regeringsreglement did not affect the primarily rural Achterhoek significantly since most power was in the hands of the nobility anyway, but it underlines the fact that its officials were supporters of the stadholder. Moreover, the government regulation is indicative of the negative attitude William and his supporters had towards the burghers who tended to be wary of the power of the Orange family. Hence, when Winterswijk merchants complained to the regional overlord about the new guild, they did not receive any sympathy from William III or his officials, because the complainants represented a group regarded as the enemy.

In fact, the merchants found they could live with the guild, especially during this period of expansion. Indeed, later guild documents show that as long as the linen trade boomed both weavers and merchants routinely ignored the charter's provisions. When the membership had plenty of work, weaving was allowed elsewhere, and payment to the various guilds in the eastern Achterhoek tended to be the same. ${ }^{43}$

4 Ibid.

42 A. H. Wertheim-Gijse Weenink, "1672-1795", in Geschiedenis van Gelderland 1492-1795, pp. 227-233; Is. An. Nijhoff, "Het Geldersche Regeringsreglement van 1675 en 1750", Bijdragen voor Vaderlandsche Geschiedenis en Oudheidkunde, VII (1850), pp. 79-96; Wayne Ph. te Brake, "Provincial Histories and National Revolution in the Dutch Republic", in Margaret C. Jacob and Wijnand W. Mijnhardt (eds), The Dutch Republic in the Eighteenth Century (Ithaca, 1992), pp. 80-82.

${ }^{43}$ G.A. Winterswijk, Archief Weversgilde, nr. 18, "Stukken betreffende het geschil tussen Aalbert and Jan Schutte en het weversgilde te Winterswijk [. . . ], Brief van Albert and Jan Schutte aan Benjamin Satink [. . .]", 16 December 1751. In general, it was not unusual for 


\section{DEPRESSION IN TEXTILE MANUFACTURING}

Unfortunately, the boom did not last, and difficulties began in 1725 when a new law reduced the duty on imported linen to 1 per cent. Merchants now faced major problems for they could barely compete with neighboring Münsterland, where wages and costs were lower by as much as 20 per cent. $^{44}$ In Winterswijk, two important reders, Jan and Albert Schutte, decided to negotiate with the guild to lower wages, triggering a conflict that was to drag on for many years, and severely testing the protection offered by the guild charter.

Beginning in 1725 the two merchants pressured the guild into agreeing to a reduction of 10 stuiver per piece of cloth. ${ }^{45}$ But, apparently, that concession was not enough: in 1728 the guild leadership complained to the Drost, the lord's local representative, that the merchants were shipping yarn to Münsterland not only by cart but even in parcels carried off by German weavers. Already several weavers in Winterswijk were without work which, according to the leadership, foreshadowed disaster for its 140 members. Since the merchants had contravened Article 3 , the guild wanted permission to search wagons, carts and parcels "by day and night". ${ }^{46}$ Now that times were bad, they demanded that the charter be enforced. The merchants, however, and the Schuttes in particular, protested that wages were too high, not just compared to those in Münsterland but even to those paid in other guilds in the eastern Achterhoek. Therefore, although they bought yarn in the same markets, other merchants could sell their linen more cheaply. Another wage reduction was felt to be in order and, yet again, the guild had to agree.

Clearly, adverse economic conditions pressured weavers into accepting these decreases in pay. Indeed their problems were not just due to lower import duties but also to increased international competition. During the first half of the eighteenth century Scotland, Ireland and England developed strong linen industries and, increasingly, they pushed Dutch linens out of the English market. ${ }^{47}$ The same thing happened in the Portuguese and huge Spanish markets, where competition from

guild regulations to be enforced more strictly during periods of economic decline while ignored at other times. See Gustafsson, "The Rise and Economic Behaviour of Medieval Craft Guilds".

4 R.A.G., Archief van Staten van Kwartier van Zutphen en hun Gedeputeerden, nr. 233b, "Requesten ingekomen bij Gedeputeerde Staten", 1592-1805, bI 1592-1756, "Request uit 1732 van coopluyden in Winterswijk".

${ }^{4}$ G.A. Winterswijk, Archief Weversgilde, nr. 18, "Stukken betreffende het geschil tussen Aalbert en Jan Schutte en het weversgilde te Winterswijk [...], Brief van Albert en Jan Schutte aan Benjamin Satink [ . . .]", 16 December 1751. There are 20 stuivers to one guilder. ${ }^{46}$ G.A. Winterswijk, Archief Weversgilde, nr. 27, "Verzoek aan de Drost door de gardiaan en gildemeesters van het weversgilde [. . . ]".

17 See A. J. Warden, The Linen Trade (London, 1864 and 1867; reprinted 1967); Harte, "The Rise of Protection and the English Linen Trade"; A. J. Durie, The Scottish Linen Industry in the Eighteenth Century (Edinburgh, 1979). 
Scotland, Ireland, Flanders, Silesia and other German regions cut into the Dutch share. ${ }^{48}$ Given these difficulties, the position of the Achterhoek weavers is clearer. Lower costs in other countries and the 1725 reduction of import duties in the Dutch Republic gave foreign cloth the edge in the market. Consequently, between 1725 and the early 1740 s, the weavers suffered. In Winterswijk, some had to pawn their "jewelry, furniture and linen" which "many, yes most could not redeem anymore". 49

Competition continued to be fierce, and again local merchants tried to have linen woven in Germany. After 1728, their technique for avoiding detection by the guild became more refined. Now, German weavers came to the merchants to pick up yarn that a villager then carried to the border. Meanwhile the German went ahead empty-handed until he was across the border where he received the materials from the Winterswijker. The guild caught a number of these violators in 1742, starting another dispute with the merchants Schutte. The Schuttes insisted that wages had to come down while the guild, conscious of dire economic conditions and desperate to take a stand, argued vainly that they could neither approve nor disapprove of any changes because, according to Article 30, the charter could be changed only by the overlord. Despite this legalistic argument, however, they had to admit that although they never gave anyone official permission to work for lower wages, people did:

since poverty among several guild brothers has intensified so much because the linen trade has been bad for a while, they have been forced to weave for whatever price they could get, if they did not want to starve with their wives and children. ${ }^{50}$

Having admitted that reality, the guild reluctantly expressed its willingness to negotiate:

But to show that the petitioners do not wish to act unlawfully against the brothers Schutte, as they imply unjustly in their request, the petitioners concede that, concerning their trade, an accommodation can be made with regard to wages, which accommodation the petitioners are prepared to consider in all reasonableness and wish to facilitate $[\ldots]^{\text {s1 }}$

Eventually, they reached an unofficial agreement that reduced payments another 10 stuiver per piece of cloth (Table 1). The merchants promised to go back to the old levels when things improved. ${ }^{52}$

\footnotetext{
${ }^{4}$ See Bel, Die Linenhandel van Amsterdam, pp. 59-63, 123; Johan de Vries, De Economische Achteruitgang der Republiek in de Achttiende Eeuw (Leiden, 1968), pp. 102-103.

49 G.A. Winterswijk, Archief Weversgilde, nr. 18, "Memorie ofte instructie voor de toecomende overluyden van het weversgilde", 12 August 1752.

so G.A. Winterswijk, Archief Weversgilde, nr. 17, "Stukken betreffende het geschil tussen Aalbert and Jan Schutte en het weversgilde te Winterswijk [ . . ], Brief van het Gilde aan de heer Derk Hoppenbrouwer [. . . ], 1743".

"lbid.

32 G.A. Winterswijk, Archief Weversgilde, nr. 18, "Memorie ofte instructie voor de toecomende overluyden van het weversgilde", 12 August 1752.
} 
Table 1. Payments in Winterswijk for woven linen cloth

\begin{tabular}{lllllll}
\hline \hline $\begin{array}{l}\text { Number } \\
\text { of threads } \\
\text { in weft }\end{array}$ & $\begin{array}{l}\text { Pre-1725 } \\
\text { at least }\end{array}$ & $\begin{array}{l}\text { After } \\
1725\end{array}$ & 1743 & $\begin{array}{l}\text { Proposed } \\
1751\end{array}$ & Proposed 1752 \\
\cline { 2 - 7 } & Amount & Amount & Amount & Amount & Amount & $\begin{array}{l}\text { Value } \\
\text { in goods }\end{array}$ \\
\hline 1000 & 3.10 & 3 & 2.10 & 3.05 & 3.05 & 3.10 \\
1100 & 4 & 3.10 & 3 & 3.15 & 3.15 & 4 \\
1200 & 4.10 & 4 & 3.10 & 4.07 .8 & 4.10 & 5 \\
1300 & 5.10 & 5 & 4.10 & 5 & 5 & 5.10 \\
1400 & 6.10 & 6 & 5.10 & 5.12 .8 & 5.10 & 6 \\
\hline \hline
\end{tabular}

All pieces of cloth had to be $52 \mathrm{el}$ long (one $e l$ is approximately $60 \mathrm{~cm}$.).

Amounts are in guilders, stuivers (20 to a guilder) and penningen (12 to a stuiver).

Source: G.A. Winterswijk, Archief Weversgilde, Nr. 18, Stukken betreffende het geschil tussen Aalbert and Jan Schutte en het weversgilde te Winterswijk [. . . . "Brief van Albert en Jan Schutte aan Benjamin Satink [...]".

\section{REGAINING LOST GROUND}

Despite the apparent strength of their charter, the weavers had lost much ground after 1725 . They had been unable to stop lower payments, and even during an upsurge in the linen trade from 1745 to 1748 , when the War of Austrian Succession disturbed the Silesian and Austrian Netherlands' (Flanders) trade, they did not regain anything they had lost. Could the guild not protect its members during economically difficult times? It appears that way, except that some documents dating from 1751 and 1752 suggest that losses were due less to the content of the charter than to a lack of determination to fight on the part of the leadership.

After 1748 , the linen trade declined from its wartime heights. During the course of 1751, the Winterswijk merchants, led by the infamous Schuttes, tried to take advantage of the situation by lowering wages again. However, this time the guild leadership refused to allow it. They decided to fight to restore the guild to its old glory, and to refuse to work for less money "than in the past". According to their rationale, they were upset that the previous leadership had not tried to restore payments during the war, and they realized that if they did not fight back now, the long-term result would be the destruction of the guild charter. The entire membership supported this resolve by word and by deed: they demanded a return to the old payment levels, and from October 1751 until 12 February 1752 seventeen men guarded the roads by day and by night to make sure no yarn would leave the area. ${ }^{33}$ Article 3 of the charter provided the legal

33 G.A. Winterswijk, Archief Weversgilde, nr. 18, "Stukken betreffende het geschil tussen Aalbert en Jan Schutte en het weversgilde te Winterswijk [. . .]", "Memorie ofte instructie voor de toecomende overluyden van het weversgilde", 12 August 1752. See also "Brief van Albert en Jan Schutte aan Benjamin Satink [. . . ]", 16 December 1751. From the documents it is not clear which level of payment the guild wanted to have restored. However, judging 
basis for this action, whose validity was confirmed by an announcement issued by the substitute drost on 18 October, pointing out that the charter forbade weaving of yam outside the guild. ${ }^{54}$

The refusal to work for less pay and guarding the roads had some results: in December 1751, Albert and Jan Schutte wrote a long petition to the Drost protesting about the guards who had stopped and searched them for yarn on the road outside the village. They argued that Winterswijk had received a guild charter only because it used to have one similar to other villages, and therefore should not be allowed to be different from them. The weavers should accept the same rules and the same levels of payment that applied elsewhere, which meant that yarn could be woven outside the guild, and "customary payments" could go down. Consistent with this argument, the Schuttes proposed new payments on 16 December 1751 , in line with pay in neighboring Groenlo, Eibergen and Borculo (see Table 1). On 27 December, the guild responded that they would not discuss the offer but would continue strictly to adhere to the charter - in effect saying that they did not accept the offer and would continue to guard against smuggling. This resulted in several more confrontations on the road between guards and the Schuttes, which, on 12 February 1752, led to a second proposal from the latter. The money rates offered were virtually the same as before, but now they offered payments in kind as well to a value that was closer to the pre-1725 rates (Table 1 ). Nevertheless, the guild rejected the offer and insisted on the old payments. The Schuttes finally acquiesced; the guild had won and withdrew its guards. ${ }^{5 s}$

The leadership clearly was very happy with the victory: they had stood up successfully to the merchants, and the charter had proven to provide adequate protection. But they were aware that without their vigilance and willingness to fight at that time to stop the slow decline of the guild, the charter could easily have been destroyed. Having a strong charter was not enough: the membership had to be willing to defend it through direct action and in court. Indeed, to make sure that future leaders were aware that such a struggle and victory were possible, the leadership wrote a brief summary of the dramatic contest and its background entitled "Memo or instruction for the future leaders of the weavers' guild"..$^{56}$ It appears that their success was long-lasting. No other records of confrontations exist for

from the proposals made by the merchants in 1751 and 1752 , which the weavers rejected (see Table 1), they meant wages paid prior to 1725 .

st G.A. Winterswijk, Archief Weversgilde, nr. 29, "Publicatie van de substituut drost van Bredevoort [...]", 18 October 1751.

ss G.A. Winterswijk, Archief Weversgilde, nr. 18, "Stukken betreffende het geschil tussen Aalbert en Jan Schutte en het weversgilde te Winterswijk [. . .]", "Memorie ofte instructie voor de toecomende overluyden van het weversgilde", 12 August 1752, and "Notitie opgetekend door S. J. Hengel Junior, voogd en Bediende van 't Gilde", 12 February 1752.

${ }^{56}$ G.A. Winterswijk, Archief Weversgilde, nr. 18, "Stukken betreffende het geschil tussen Aalbert en Jan Schutte en het weversgilde te Winterswijk [. . . ]", "Memorie ofte instructie voor de toecomende overluyden van het weversgilde", 12 August 1752. 
the rest of the century when the guild was abolished after the Batavian Revolution of 1795.

\section{CONCLUSION}

The history of the Winterswijk weavers' guild demonstrates that the introduction of capitalist production was not a quick and easy process, even in a situation where merchants were economically more powerful than producers. By the end of the seventeenth century, the merchants of Winterswijk had already significantly curtailed the independence of the weavers through their control over the supply of raw materials. Nevertheless, when they attempted to use their power to lower pay rates and set weavers against each other, weavers fought back by adapting old and familiar "weapons" to new circumstances: in this instance the governing rules of their new guild charter. Adapting an old weapon such as a guild was particularly effective because it was an organization that local officials had dealt with in the past, and whose rules they were willing to enforce.

The Winterswijk weavers, of course, had an additional political advantage in that William III's officials were not well disposed toward merchants. It is not automatic, however, that government officials would have supported the merchants if the political situation had been different. Indeed, the opinion expressed by the local official looking into complaints against the guild represented a traditional view: maintaining "rule and order" meant enforcing long-established, accepted rules that promoted social well-being and the public good by preventing "disorders and collusions" between merchants and especially foreign weavers. ${ }^{57}$ The official did not regard the link between merchants and outside weavers as economically progressive but as destructive of the livelihood of Winterswijk weavers. Therefore, the merchants created disorder, and only by supporting the guild could order be restored.

This attitude was not unique to the area or even to the Dutch Republic. There is evidence that in France, prior to the French Revolution, it was not unusual for government officials to enforce existing rules and laws of commerce even if they went against economically more powerful merchants. In southern Anjou in the 1780 s, officials insisted on strict observance of the rules of the market-place in order to protect independent producers from monopolistic practices of merchants. The language used by the French official is strikingly similar to that used by the Achterhoek official quoted above. Both used words like "monopolist', "order", and "disorder", and although written a hundred years apart, both expressed the same concerns and attitude toward merchants. ${ }^{58}$ Even in England,

37 G.A. Winterswijk, Archief Weversgilde, nr. 31, "Stukken betreffende het verzet [. . .]", 1684-1686, "Brief van de heer Griff. Tollius", 27 July 1684.

sa Tessie P. Liu, "The Embattled Origins of the Putting-Out System: A Reassessment of the Proto-industrialization Hypothesis", in Working Papers No. 1 issued by the Atlanta Seminar 
where the capitalist economy was most advanced, officials did not automatically choose the merchants' side. In his discussion of food riots in eighteenth-century England, E. P. Thompson indicates that sometimes authorities were willing to enforce traditional rules of the market against new middlemen. Many gentlemen resented grain dealers, and were not displeased when they were attacked. Indeed, some country magistrates refused to act on disturbances directed against middlemen, and sometimes they actually enforced existing laws against, e.g. forestalling. ${ }^{59}$

Hence, incorporating new rules in a charter that established an apparently traditional organization strengthened the weavers' position against the merchants. History and custom were on their side, and it was the merchants who were seen as changing the status quo. It made it easier for weavers to appeal to the authorities, and as long as capitalist views of the market were not dominant, officials were likely to view their complaints as legitimate. Obviously, in the long run, even these innovative weavers in Winterswijk could not stop the oncoming tide of capitalism, but at least they succeeded in slowing it for a time, allowing a few more generations of weavers to retain some independence.

in the Comparative History of Labor, Industry, Technology, and Society, 1992. Also compare the magistrates' action in Den Bosch in 1775. See Prak, "'Een Verzekerd Bestaan"', pp. 76-77.

${ }^{39}$ See "The Moral Economy of the English Crowd in the Eighteenth Century", Past \& Present, L (1971), pp. 88ff, 94ff. 